\title{
KEPATUHAN MINUM OBAT DAN DUKUNGAN KELUARGA TERHADAP KEKAMBUHAN PASIEN SKIZOFRENIA
}

\author{
${ }^{1}$ Dian Yuniar, ${ }^{2}$ Sumirah Budi Pertami \\ ${ }^{1}$ Department of Nursing, Polytechnic of Health Kendari, ${ }^{2}$ Polytechnic of Health Malang, \\ Ministry of Health of The Republic of Indonesia \\ e-mail :dian.yuniar.sr@gmailcom
}

\begin{abstract}
Abstrak
Penelitian ini bertujuan untuk mengetahui hubungan kepatuhan minum obat dan dukungan keluarga terhadap kambuh dan tidak kambuh pada pasien rawat jalan skizofrenia. Penelitian ini adalah penelitian analitik pendekatan cross sectional dilaksanakan di Ruang Rawat Jalan dan Unit Gawat Darurat Rumah Sakit Jiwa Provinsi Sulawesi Tenggara Kota Kendari. Jumlah responden 73 dari 311 penderita skizofrenia, diambil dengan metode aksidental sampling data diolah secara univariat dan bivariat berdasarkan hasil Uji chi Square variabel kepatuhan minum obat diperoleh nilai $p=0,001$ dan dukungan keluarga $p=0,003$ artinya Kepatuhan minum obat, dukungan keluarga, berhubungan terhadap kambuh dan tidak kambuh pada pasien rawat jalan skizofrenia. kesimpulan penelitian bahwa pendekatan psikososial dalam menangani kekambuhan pada pasien rawat jalan skizofrenia, seperti terapi keluarga, psikoterapi individual, pelatihan keterampilan sosial dan perlakuan komunitas disarankan untuk menurunkan angka kekambuhan pasien skizofrenia.
\end{abstract}

Kata Kunci: Kepatuhan Minum Obat, Dukungan Keluarga, Skizofrenia

\begin{abstract}
The purpose of research is to analyze the correlation between discipline to swallow medicine and family support of flaring up more or not of schizophrenia patients treated. Characteristic of research is descriptive analysis using cross-sectional approach. Research has been held at outpatient ward and emergency ward Mental Hospital of Southeast Sulawesi Province. Samples amount of research is 73 respondents from 311 patients of schizophrenia disease, taken by using accidental sampling method. Data processed in univariant and bivariant coverage cross tabulation. Based on chi-Square test result risk estimate variable of discipline to swallow medicine obtained value of $p=$ 0,001 and family support obtained a value of $p=0,003$. The conclusion of research; discipline to swallow the medicine, family support have significant correlations to flaring up more of schizophrenia patients. The psychosocial approach in handling flare up more, such as family therapy, individual psychotherapy, training of social skills, and community treatment, suggested to reduce flaring up of patients suffering from schizophrenia disease.
\end{abstract}

Keywords: Discipline to Swallow Medicine, Family Support, Schizophrenia

\section{PENDAHULUAN}

Menurut data World Health Organization WHO (2001) di dunia terdapat paling tidak satu dari empat orang di dunia atau 450 juta orang terganggu kesehatan jiwanya (Wirnata, 2009). Prevalensi penderita skizofrenia di Indonesia sekitar 0,3 sampai $1 \%$ dan biasanya timbul pada usia sekitar $18-45$ tahun, akan tetapi ada juga yang baru berusia 11 - 12 tahun sudah menderita skizofrenia.

Berdasarkan data dari Departemen Kesehatan jumlah penderita penyakit jiwa berat sekitar 6 juta orang atau sekitar 2,5\% dari total penduduk di Indonesia. Ada beberapa hal yang bisa memicu kekambuhan skizofrenia, antara lain penderita tidak minum obat teratur, tidak memeriksakan diri ke dokter secara teratur, menghentikan obat tanpa persetujuan dari dokter, kurangnya dukungan dari keluarga terdekat dan masyarakat dilingkungan rumahnya, adanya permasalahan yang berat pencetus stress, sehingga penderita kambuh dan dirawat kembali di rumah sakit. Klien dengan diagnosa skizofrenia diperkirakan akan kambuh $50 \%$ tahun pertama dan $70 \%$ tahun kedua setelah pulang dari rumah sakit serta 
angka kekambuhan $100 \%$ pada tahun kelima (Videbeck, 2007).

Pada tahun 2010 terdapat 3.219 orang kunjungan rawat jalan penderita skizofrenia, yang kambuh 705 orang kunjungan rawat inap, tahun 2011 terdapat 3.147 orang kunjungan rawat jalan penderita skizofrenia, yang kambuh 675 orang kunjungan rawat inap, tahun 2012 meningkat menjadi 3.743 orang kunjungan rawat jalan penderita skizofrenia, yang kambuh 682 orang kunjungan rawat inap dengan kasus yang sama (Rumah Sakit Jiwa Provinsi Sulawesi Tenggara, 2012).

Hasil observasi penulis di poli klinik Rumah Sakit Jiwa (RSJ) Provinsi Sulawesi Tenggara menunjukkan terdapat beberapa penderita yang kembali dirawat. Pasien yang kembali dirawat dikarenakan tidak mau minum obat dan kontrol ke dokter. Keluarga merasa malu dan tidak sanggup untuk merawat serta banyak anggapan masyarakat sangat berbahaya dan sebaiknya dihindari, selain itu hasil wawancara dengan keluarga pasien sebagian besar dari mereka mengatakan kesulitan dalam hal pengobatan hal ini dikarenakan jarak tempuh ke Rumah Sakit terlalu jauh. Berdasarkan latar belakang tersebut maka peneliti ingin melihat hubungan kepatuhan minum obat dan dukungan keluarga terhadap kekambuhan pasien rawat jalan skizofrenia.

\section{METODE PENELITIAN}

Penelitian ini mengunakan pendekatan cross sectional. Teknik pengambilan sampel adalah aksidental sampling. Data primer yang dikumpulkan menggunakan kuisioner dan lembar observasi yang dikembangkan sendiri oleh peneliti dengan mengacu pada kerangka konsep berdasarkan tinjauan pustaka. Analisa data yang dilakukan adalah analisa univarait dan analisa bivariat sesuai varaiabel penelitian. Analisa bivariat menggunakan uji chi-quare.

\section{HASIL PENELITIAN}

Distribusi frekuensi berdasarkan kelompok umur yaitu umur 28-35 tahun merupakan jumlah terbanyak yaitu 24 orang
$(32,8 \%)$, kelompok umur $36-43$ tahun berjumlah 18 orang $(24,8 \%)$, kelompok umur 20-27 tahun berjumlah 16 orang $(21,9 \%)$, kelompok umur 44-50 tahun berjumlah 5 orang $(6,8 \%)$ dan golongan umur $>51$ tahun berjumlah 10 orang (13,8\%). Berdasarkan pendidikan responden yang diteliti yaitu pendidikan tinggi berjumlah 37 orang $(50,7 \%)$, pendidikan SMA berjumlah 22 orang $(30,2 \%)$, pendidikan SMP berjumlah 8 orang $(10,9 \%)$, pendidikan SD berjumlah 2 orang $(2,7 \%)$, dan tidak sekolah berjumlah 4 orang $(5,5 \%)$.

Distribusi frekuensi responden berdasarkan jenis pekerjaan yaitu pekerjaan sebagai PNS merupakan jumlah terbanyak berjumlah 35 orang $(47,9 \%)$, pekerja swasta berjumlah 18 orang $(24,7 \%)$, pekerja wiraswasta berjumlah 14 orang $(19,2 \%)$, dan yang ibu rumah tangga berjumlah 6 orang $(8,2 \%)$.

Distribusi frekuensi responden berdasarkan hubungannya dengan pasien menunjukan bahwa hubungan responden dengan pasien yaitu hubungan sebagai saudara dengan pasien merupakan jumlah terbanyak yaitu 38 orang $(52,1 \%)$, hubungan orang tua dengan pasien berjumlah 13 orang (17,8\%), hubungan Istri dengan pasien berjumlah 12 orang $(16,4 \%)$, hubungan anak dengan pasien berjumlah 10 orang $(13,7 \%)$.

Analisis Bivariat meliputi hubungan kepatuhan minum obat dan dukungan keluarga terhadap kekambuhan pasien rawat jalan skizofrenia. Analisis hubungan kedua variabel tersebut dapat disajikan pada table di bawah ini.

Tabel 1. Hubungan kepatuhan minum obat dengan kekambuhan pasien skizofrenia

\begin{tabular}{cccc}
\hline \multirow{2}{*}{$\begin{array}{c}\text { Kepatuhan } \\
\text { Minum obat }\end{array}$} & \multicolumn{2}{c}{$\begin{array}{c}\text { Kekambuhan } \\
\text { Skizofrenia }\end{array}$} & Jumlah \\
\cline { 2 - 3 } & Kambuh & Tidak & \\
\hline Patuh & 18 & 20 & 38 \\
\hline Tidak & 30 & 5 & 35 \\
\hline Jumlah & 48 & 25 & 73 \\
\hline$\rho=0,001 \& x^{2}=11,897$ & &
\end{tabular}

Berdasarkan tabel 1. menunjukan bahwa dari 73 responden ada 30 orang $(41,1 \%)$ yang tidak patuh dengan status kambuh sedangkan 20 orang (27,4\%) responden yang patuh dengan status tidak 
mengalami kekambuhan. Nilai $x$ hitung diperoleh dari hasil crosstabs risk estimate adalah 11,897 dan yang berarti bahwa kepatuhan berhubungan secara signifikan dengan kekambuhan pasien rawat jalan skizofrenia. Responden dengan ketidakpatuhan minum obat mempunyai resiko untuk mengalami kekambuhan 11,897 kali lebih besar dibandingkan dengan responden yang patuh dalam minum obat.

Tabel 2. Hubungan dukungan keluarga dengan kekambuhan pasien skizofrenia

\begin{tabular}{cccc}
\hline \multirow{2}{*}{$\begin{array}{c}\text { Dukungan } \\
\text { Keluarga }\end{array}$} & \multicolumn{2}{c}{$\begin{array}{c}\text { Kekambuhan } \\
\text { Skizofrenia }\end{array}$} & Jumlah \\
\cline { 2 - 3 } & Kambuh & Tidak & \\
\hline Mendukung & 19 & 19 & 38 \\
\hline Tidak & 29 & 6 & 35 \\
\hline Jumlah & 48 & 25 & 73 \\
\hline$\rho=0,003 \& x^{2}=8,735$ & &
\end{tabular}

Berdasarkan tabel 2. Menunjukan bahwa ada $19(26,1 \%)$ responden yang memberikan dukungan keluarga dengan status tidak kambuh, sedangkan $29(39,7 \%)$ responden yang tidak memberikan dukungan keluarga dengan status kambuh. Nilai X.Hitung yang diperoleh dari hasil crosstabs risk estimate adalah 8,735 yang berarti bahwa dukungan keluarga berhubungan secara signifikan dengan kekambuhan pasien rawat jalan skizofrenia diterima. Responden yang tidak mendapat dukungan keluarga mempunyai resiko untuk mengalami kekambuhan 8,735 kali lebih besar dibandingkan dengan responden yang mendapat dukungan keluarga.

\section{PEMBAHASAN}

Hasil analisis univariat menunjukkan sekitar 35 orang $(47,9 \%)$ yang tidak patuh minum obat terhadap kambuh dan tidak kambuh pada pasien rawat jalan skizofrenia dengan frekuensi kambuh sebanyak 3 kali perawatan. Hal ini dapat disebabkan oleh adanya reaksi efek samping yang dirasakan oleh pasien, obat yang diberikan memberikan efek samping terlebih dahulu dari pada reaksi positif dari obat antipsikotik Stuart (2006). Pasien yang menerima regimen pengobatan yang terintegrasi, misalnya mengkonsumsi beberapa obat dengan waktu yang berbeda dalam satu hari atau mengkonsumsi dua macam atau lebih obat-obatan, mempunyai permasalahan dalam ketaatan terhadap obat yang diberikan dibandingkan pasien yang hanya mengkonsumsi obat dosis tunggal.

Permasalahan lain mengenai kepatuhan pengobatan yang dikemukakan oleh keluarga pasien berdasarkan hasil wawancara adalah masalah keuangan, dimana beberapa pasien kemungkinan tidak mampu untuk membeli obat atau jarak tempuh dan transportasi dapat menjadi penghalang. Hasil analisis menunjukkan pemberian dukungan keluarga terhadap kambuh dan tidak kambuh pada pasien rawat jalan skizofrenia yaitu yang tidak memberikan dukungan berjumlah 35 orang (47,9\%). Sejalan dengan itu Hawari (2006) mengatakan bahwa anggota keluarga sangat membutuhkan dukungan dari keluarganya karena hal ini membuat penderita merasa dihargai dan setiap anggota keluarga terdekat siap memberikan dukungan untuk menyediakan bantuan dan tujuan hidup yang ingin dicapai oleh individu.

Mempunyai anggota keluarga yang menderita skizofrenia memang bukanlah hal yang mudah, namun bantuan dan dukungan dari keluarga sangat dibutuhkan dalam proses penyembuhan pasien skizofrenia, adanya masalah emosi dalam keluarga yang dapat mempengaruhi kekambuhan pada pasien skizofrenia, berbagai kalangan berpendapat stigma dapat bermanifestasi dalam bentuk keinginan memasukkan anggota keluarga yang menderita gangguan mental berat kerumah sakit jiwa.

Kepatuhan minum obat merupakan faktor resiko yang pertama untuk memperkuat kekambuhan tidak terjadi. Masalah keuangan dapat mengganggu kepatuhan minum obat, hal ini dikarenakan kondisi keuangan yang tidak memungkinkan untuk membeli obat atau bisa saja mampu untuk membelinya namun jarak tempuh dan sarana transportasi yang tidak ada dapat menjadi penghalang (fleischacker, 2009). Hal ini dapat dilakukan dengan mempertimbangkan variabel-variabel yang berpengaruh secara signifikan terhadap kejadiaan skizofrenia, khususnya kepatuhan minum obat sebagai variabel yang 
memberikan kontribusi terbesar terhadap kambuh dan tidak kambuh pada pasien rawat jalan skizofrenia.

\section{KESIMPULAN}

Dukungan keluarga berhubungan secara signifikan terhadap kambuh dan tidak kambuh pada pasien rawat jalan skizofrenia di RSJ Provinsi Sulawesi Tenggara dan sebaiknya pihak Rumah Sakit perlu melakukan pendekatan psikososial dalam menangani kekambuhan pada pasien rawat jalan skizofrenia, seperti terapi keluarga, psikoterapi individual, pelatihan keterampilan sosial dan perlakuan komunitas. Keluarga penderita skizofrenia lebih memperhatikan pasien terhadap kepatuhan minum obatnya dan memberikan dukungan untuk melakukan kegiatan yang dapat mengurangi derajat stress seperti mengisi waktu senggang dengan melakukan aktifitas fisik, meningkatkan rutinitas ibadah kepada sang pencipta untuk memperoleh ketenangan dan sebaiknya pemerintah dan masyarakat daerah setempat memberikan dukungan dan kesempatan pada penderita untuk melakukan kegiatan yang dilaksanakan di daerah setempat tanpa ada justifikasi bahwa mereka adalah penderita gangguan jiwa.

\section{DAFTAR PUSTAKA}

Ahmadi. A, (2006). Psikologi Belajar. Rineka Cipta: Jakarta.

Andreas. I, (2008). Schizophrenia (Online) (http://www.indonesiaonline.org)

Arif, I.S., (2006). Skizofrenia Memahami Dinamika Keluarga Pasien. Refika Aditama: Bandung.

Carson. R.C. dkk, (2007). Abnormal Psychology and Modern Life 11th ed. Allyn dan Bacon: Needham Heights.

Chandra. B, (2008). Metodologi Penelitian Kesehatan. Penerbit Buku Kedokteran, EGC: Jakarta.

Depkes R.I, (2006). Pedoman dan Penggolongan dan Diagnosis Gangguan Jiwa Indonesia. Depkes: Jakarta.

Durand. M.V, (2007). Intisari Psikologi Abnormal Pustaka Belajar. Depkes RI: Yogyakarta.
Erwin, (2008). Pengertian Skizofrenia. Dibuka pada website februari 2013

Fleischacker. W, (2009). (Online) Facktor influencing Complaince in Schizoprenia di akses februari 2013.

Friedman. M, (2005). Keperawatan Keluarga Teori dan Praktik. EGC: Jakarta.

Hamid S.A.Y, (2008). Bunga Rampai:Asuhan Keperawatan Jiwa. EGC: Jakarta.

Hawari. D, (2007). Pendekatan Holistik pada Gangguan Jiwa Skizofrenia. Edisi 3. Balai Penerbit FKUI: Jakarta.

Hoeksema, (2006). Skizofrenia. EGC: Jakarta.

Isaacs, (2005). Keperawatan Kesehatan Jiwa \& Psikiatri. Edisi 3. EGC: Jakarta.

Kartono. K., (2006). Patologi Sosial 3: Gangguan-Gangguan Kejiwaan. EGC: Jakarta.

Keliat, B.A., (2006). Peran Serta Keluarga Dalam Perawatan Klien Gangguan Jiwa. EGC: Jakarta.

Kino. B.J, (2005). (Online) (Olanzapine Oraly Disintegrating Tablets In The Treatment Of Actualy III Non-Compalint Patient With Schizophrenia. International Journal Of Neuropsycho pharmacology P.97-102) diakses Februari 2013.

Maramis, (2007). Ilmu Kedokteran Jiwa. Airlangga Universitas. Cetakan IV: Surabaya.

Marilyn. M, (2006). Keperawatan Keluarga. EGC: Jakarta.

Maslim. R, (2006). Buku Saku Diagnosis Gangguan Jiwa Rujukan Ringkas. PPDGJ-III: Jakarta.

Nursalam, (2008). Konsep dan Penerapan Metodologi Penelitian IImu Keperawatan. Salemba Medika: Jakarta.

Parawisata. A, (2006). (Online) (http ://www. faktor kekambuhan skizofrenia. com.htm)

RSJ Provinsi Sulawesi Tenggara, (2010). Profil Rumah Sakit Jiwa Provinsi Sulawesi Tenggara: Kendari.

Sadock, (2006). (Online) Consep of schizophrenia. Lippincote

Sena.EP et all, 2006. (Online) Relapse In Patients with Schizophrenia 
Setiadi, (2006). Konsep dan Proses Keperawatan Keluarga. Edisi 1. Graha IImu: Yogyakarta.

Stuart. WG \& Sundeen J.S, (2006). Keperawatan Jiwa. Edisi 5. EGC: Jakarta.

Sugiyono, (2008). Statistika Untuk Penelitian. Alfabeta: Bandung.

Suliswati, 2005. Konsep Dasar Keperawatan Jiwa. EGC: Jakarta.

Susanto, (2010). Metodologi Penelitian. Kesehatan. Rineka Cipta: Jakarta.

Wirnata. M, (2009). (Online) (http://www. Skizofrenia|Keperawatan-kesehatan Jiwa kekambuhan.htm).

Wulansih. S, 2008. (Online) (http://etd.eprints. ums.ac.id/900/1/J220060029.pdf)

Yasril \& Kasjono. HS, (2009). Analisis Multivariat Untuk Penelitian Kesehatan. Mitra Cendekia: Yogyakarta.

Videbeck. S. L, (2007). Buku Ajar Keperawatan Jiwa. EGC: Jakarta. 